\title{
Typomorphic characteristic features of accessory ilmenite in granitoids of the polyphase Aleisk-Zmeinogorsk complex (N-W Rudny Altai area)
}

\author{
Novoselov K.L. ${ }^{1}$, Gavrilova K.A. ${ }^{1}$ \\ ${ }^{1}$ National Research Tomsk Polytechnic University, 30 Lenina Ave., Tomsk, 634050, Russia
}

\begin{abstract}
The paper material is devoted to the research of crystallomorphology, accessory ilmenite expansion, characteristic features of its chemical composition, paragenetic association and conditions for mineral formation in Devonian granitoids of the polyphase Aleisk-Zmeinogorsk complex. Two ilmenite generations formed at various crystallization stages of the magmatic melt have been identified by the morphological features of the ilmenite crystals, chemical composition and paragenesis. Early-magmatic Ilmenite 1 singled out at the protocrystallization stage during reduction and weakly-oxidizing environment conditions. It is characterized by the crystalline-faced shapes, low content of the pyrophanite minal and V admixture. Ilmenite 2 singled out at the major crystallization stage of the melt in the conditions of higher oxygen fugacity as the forms of the flattened, xenomorphic grains with the enhanced pyrophanite concentration and $\mathrm{Nb}$ admixture.
\end{abstract}

\section{Introduction}

Generally speaking, Rudny Altai is considered to be a unique metallogenic province with the precious, rare and iron-ore deposits. Though, the problems on the geochemical trend and potential granitoids ore-bearing in Aleisk-Zmeinogorsk complex $\left(\mathrm{D}_{2-3}\right)$, which occupies the larger part of the north-west of Rudny Altai, are obscure and nowadays relevant.

Target of the research is to analyze accessory ilmenite distribution relationships as the essential mineral and $\mathrm{Ti}$ concentrator, characteristic features of its crystallomorphology and chemical composition in granitoids of the successive intrusive phases.

Research methods besides traditional (mineralogo-petrochemical) included accessory mineral one. It analyzed granitoid crushed samples according to the routine scheme [1], sampling monomineral ilmenite fractions to calculate the content and provide analytical research. The ilmenite chemical composition was identified by the electronic scanning microscope JSM-6510LV (Jeol Ltd) (SNIIGGIMS laboratory, Novosibirsk, M.V Khlestov, analystresearcher) and X-ray fluorescence microscope (Department of Geology and Minerals Prospecting, Institute of Natural Resources, (analyst M.A. Rudmin, candidate in science (Geology \& Mineralogy) ).

\section{Petrologo-geochemical description of granitoids from Aleisk-Zmeinogorsk complex}

Aleisk-Zmeinogorsk complex $\left(\mathrm{D}_{2-3}\right)$ includes three big granitoid massifs (Novonikolayevskiy, Aleiskiy, Ustyanskiy) and some smaller bodies localized in the north structures of Aleisk uplift in Rudny Altai. These are between Devonian volcanogenic sedimentary depressions, controlled by the deep-seated faults of the north-western and sublatitudinal strike, characterized by comagmatic connection with Devonian vulcanites of Kamenevskiy complex [2]. The biggest territory (more than $1000 \mathrm{~km}^{2}$ ) is occupied by Novonikolayevskiy batholith, located in the north end of Aleisk anticlinorium. It has a comlex polyphase texture, comprising the whole range of homodromous succession - from early gabbroid to the fourth final leucogranitic phase with biotite and biotite- muscovite differences. Gabbroids - derivatives from the first phase intrusion - are intensively metamorphosed and form small xenolith bodies in the granitoids of the later phases. The derivatives of the second, major phase are widespread. These are plagiogranits, tonalites; of the fourth final phase - the leucogranits. The basic petrochemical characteristics of granitoids are the following: (from plagiogranits and tonalities of the early phase to leucogranits of the final) 1) agpaitic and total alkalinity ratios increase in the rocks due to $\mathrm{Na}_{2} \mathrm{O}$ domination over $\mathrm{K}_{2} \mathrm{O} ; 2$ ) rock alumina al' notably increases, so does the ferruginosity ratio $f$ 
(from 0.77 to 3.75$)$, when the sustained iron oxidation ratio is $\mathrm{F}(0.81-0.84)$; the rock calcareousness and titanium rates decrease $(9.89-5.44)$.

The characteristic features of granitoids are the following: sulfer scarcity and absence of admixture elements referring to the chalcophile group, limited set and low content of siderophiles like $\mathrm{Co}, \mathrm{Ni}, \mathrm{Cr}$, $\mathrm{Sc}$, V which mainly concentrate in the earliest granitoid melt differentiates. Lithophile elements represent the most abundant group, where $\mathrm{Ti}$ content in the major phase plagiogranits exeeds the bulk earth value (concentration criterion Ti (KкTi) is $1.22-2.2$. КкТі decreases to $0.95-0.43$ in the later rock phases. Moreover, granitoids are substantially enriched by rare earth elements, including $\mathrm{Y}$, that forms excess concentrations (ККY $=1.25-1.95)$.

Titanomagnetite-ilmenite-zircon-apatite-sphene-orthite association is considered to be the leading accessory minerals association in plagiogranits and tonalities relating to the major phase. Hematite, rutile, martite, rare earth elements significance becomes substantially greater when the ilmenite and sphene contents decrease. This occurs in granitoids of the second, third and the final (the fourth) intrusion phases among the accessory minerals.

By the formation conditions the granitoid massifs of the complex are thought to be the individualized parts of the large pluton formed from the unique magmatic center of the activated continental margin in the Middle-Late Devonian. These are associated with the granites of the I-type [2]; hypabyssal facies is responsible for the formation depth. Both, the calculated rocks crystallization temperature and oxygen fugacity according to mineralogical and petrochemical geothermometres [3] are at $900-850^{\circ} \mathrm{C}$ when $\lg f_{\mathrm{O} 2}$ is from 17.5 to 13.5 .

\section{Results and discussion}

Ilmenite is a low-magnetic and electromagnetic fraction in the association with the titanomagnetite, hematite, ferrorutile, and forms low concentrations in granitoids; is irregularly distributed both along the plagiogranits massif area in the major phase, and in the derivatives of the successive phases. It is widespread in plagiogranite, tonalite and in the fourth final leucogranitic phase. Ilmenite occurs in the third leucoplagiogranite phase, but only in the solid solution of titanomagnetite decomposition texture in the form of the parallel-oriented thin lamella. Ilmenite crystallizes at the magmatic stage in the wide temperature range of reduction and weakly oxidizing conditions [4, 5, 6, 7]. The absence of accessory ilmenite grains in the third leucoplagiogranite intrusion phase is due to the oxygen activity increase during their formation. This resulted in ferrorutile occurrence, characterized by Mn admixture as a substitute for ilmenite [3].

Ilmenite constantly occurs in the major phase plagiogranite, but its content is not constant and doesn't increase $30-90 \mathrm{~g} / \mathrm{t}$. The lowest ilmenite concentrations are in the final leucogranitic phase where it is identified in the individual grains; its sample content is not more than $8 \mathrm{~g} / \mathrm{t}$.

By the crystallomorphological characteristics two types of ilmenite emanation have been determinedcrystalline-faced and flattened or platy-angular grains.

The crystalline-faced form is definitely rare one and mostly occurs in the major-phase plagiogranites. Its habit

is tabular with the size of $0.3-0.5 \mathrm{~mm}$, well-defined rhombohedron faces $\{1011\}$ and pinacoid $\{0001\}$. Cross striation often occurs on the faces (0001) as well as numerous micron -size pores and blebs of quartz, and plagioclase grains. But the widespread ilmenites in rocks are the ones which don't have simple forms faces. These are xenomorphic grains with the size of $0.1-0.3 \mathrm{~mm}$, angular or a little elongated, having indented, sinuous edges; the pinacoid faces are shown on the individual grains.

Ilmenite is usually ferrum-black; steel-grey or brownish shade appears in the crystals. The ilmenite streak on the porcelain plate is red.

Ilmenite grain forms research of petrographic thin sections has also identified its two morphological types: intergranular spaces are characterized by the ilmenite idiomorphic grains and usually accumulate early plagioclase grains $\left(\mathrm{An}_{30-50}\right)$ as well as quartz grains. Ilmenite xenomorphic grains occupy the intergranular spaces and form the hornblende intergrowths. So, the ilmenite crystalline morphology, grains interrelation with major rock-forming minerals show the ilmenite isolation during the whole magmatic stage of granitoid melt crystallization. This process provides the identification of two generations formed at different rock crystallization phases. Ilmenite1, crystalline-faced, earlymagmatic had singled out from the melt at the protocrystallization stage before major rock-forming minerals occurrence (plagioclase, potash feldspas). Ilmenite 2, xenomorphic, singled out at the mass melt crystallization stage, timeassociated with dark-colored minerals (potash feldspas, quartz).

Ilmenite1 is widespread in the major-phase plagiogranites, Ilmenite 2 grains generally occur at the final-stage leucogranites; early ilmenite crystals are rare.

The chemical composition of the identified ilmenite generations is presented in the Table.

By the obtained chemical composition data, ilmenite is characterized by the limited set of admixtures. The increased concentration of $\mathrm{Mn}$ is constantly present, $\mathrm{Al}$ admixture is occasionally determined, $\mathrm{V}$ is in Ilmenite 1 , and $\mathrm{Nb}$ is in Ilmenite 2. These elements presence is due to their occurrence in the ilmenite texture by the scheme of isovalent or heterovalent isomorphism $\mathrm{Fe}^{2+} \leftarrow \mathrm{Mn}^{2+} ; \mathrm{Ti}^{4+} \leftarrow \mathrm{Al}^{3+}, \mathrm{Nb}^{5+}, \mathrm{V}^{5+}$ [8]. In most Ilmenite 1 and Ilmenite 2 crystallochemical formulae the calculated ratios are approximate to stoichiometric values; their individual deviations for the ferrous iron might be related to $\mathrm{Fe}^{3+}$ presence that appeared to have no identification. Moreover, while calculating it was considered to be $\mathrm{Fe}^{2+}$. 
As it has been already mentioned, Mn has the greatest concentrations in ilmenite, the abundance of which sharply increases in Ilmenite 2 (up to 15.71 mas. \%) as its manganese variety - mangan-ilmenite [9]. Ilmenite manganese is in the form of minal - pyrophanite $\mathrm{MnTiO}_{3}$, isostructural with $\mathrm{FeTiO}_{3}$ forming two-component isomorphic mixture. The calculated pyrophanite content in Ilmenite1 changes from 2.9 to 19.2 mol.\%; in Ilmenite 2 the concentration of pyrophanite molecule sharply increases to $21-33 \mathrm{~mol} \%$. Al admixture is not identified in all studied crystals of the early generation, though the increased concentrations (up to 5.95 mas. \%) characterize Ilmenite1 as more aluminia-saturated of all plagiogranites. The Al admixture is present in Ilmenite 2 (leucogranites), but in smaller amount (up to 1.85 mas. \%); only separate grains have higher content (up to 5.54 mas. \%). V admixture in the amount of $0.31-0.6 \%$ is occasionally identified in early magmatic Ilmenite1(plagiogranites) of the major phase. In early magmatic Ilmenite1 (leucogranites) of the final phase the $\mathrm{V}$ admixture has not been identified. This absence relates to $\mathrm{V}$ occurrence in the crystal lattice of the widespread accessory titanomagnitite [3]. Moreover, the $\mathrm{V}$ admixture absence is explained by the increased alkalinity of the melt, significant potassium trend and volatile elements activity, particularly $\mathrm{F}$, which in complex compound with $\mathrm{V}\left[\mathrm{VF}_{5}\right]$ is capable of migration or accumulation in the residual melt [10]. Niobium is present in Ilmenite 2 (leucogranites) of the final phase, its concentration is not more than $0.3 \%$.

Table. Ilmenite chemical composition in plagiogranites (major phase) and leucogranites (final phase) mas. \%

\begin{tabular}{|c|c|c|c|c|c|c|c|}
\hline № & $\mathrm{TiO}_{2}$ & $\mathrm{FeO}$ & $\mathrm{MnO}$ & $\mathrm{Al}_{2} \mathrm{O}_{3}$ & $\mathrm{~V}_{2} \mathrm{O}_{5}$ & $\mathrm{Nb}_{2} \mathrm{O}_{5}$ & total \\
\hline \multicolumn{8}{|c|}{ Ilmenite1 } \\
\hline 1. & 48.29 & 42.6 & 5.41 & 3.1 & - & - & 99.4 \\
\hline 2. & 44.62 & 47.54 & 3.13 & 4.11 & 0.6 & - & 100 \\
\hline 3. & 46.68 & 46.33 & 2.51 & 4.48 & - & - & 100 \\
\hline 4. & 48.09 & 48.08 & 3.35 & - & 0.48 & - & 100 \\
\hline 5. & 43.13 & 44.55 & 6.18 & 5.95 & - & - & 99.81 \\
\hline 6. & 49.67 & 47.73 & 3.06 & - & - & - & 100.46 \\
\hline 7. & 50.38 & 45.75 & 4.74 & - & - & - & 100.87 \\
\hline 8. & 49.94 & 41.23 & 8.95 & - & - & - & 100.12 \\
\hline 9. & 54.06 & 42.39 & 4.56 & - & - & - & 101.01 \\
\hline 10. & 52.06 & 38.7 & 4.3 & - & 0.5 & - & 95.56 \\
\hline 11. & 52.38 & 41.26 & 5.27 & - & 0.31 & - & 99.22 \\
\hline 12. & 52.44 & 38.69 & 7.53 & - & 0.35 & - & 99.01 \\
\hline 13. & 49.62 & 47.65 & 3.54 & - & - & - & 100.81 \\
\hline 14. & 49.56 & 44.46 & 3.78 & 2.17 & - & - & 99.97 \\
\hline 15. & 59.81 & 35.34 & 2.05 & 2.81 & - & - & 100.01 \\
\hline 16. & 59.17 & 35.09 & 1.41 & 4.33 & - & - & 100 \\
\hline \multicolumn{8}{|c|}{ Ilmenite2 } \\
\hline 17. & 51.63 & 37.67 & 12.19 & - & - & - & 101.49 \\
\hline 18. & 51.34 & 32.79 & 13.96 & - & - & 0.23 & 98.32 \\
\hline 19. & 48.92 & 37.05 & 12.31 & 1.57 & - & 0.15 & 100 \\
\hline 20. & 48.87 & 40 & 9.17 & 1.74 & - & 0.22 & 100 \\
\hline 21. & 48.7 & 39.73 & 10.18 & - & - & 0.18 & 98.79 \\
\hline 22. & 46.13 & 36.47 & 15.19 & 1.85 & - & 0.2 & 99.84 \\
\hline 23. & 47.29 & 33.39 & 14.86 & 4.17 & - & 0.29 & 100 \\
\hline 24. & 46.12 & 32.08 & 15.71 & 5.54 & - & 0.3 & 99.75 \\
\hline
\end{tabular}

Note: 1) $\mathrm{FeO}$ as $\mathrm{FeO}+\mathrm{Fe}_{2} \mathrm{O}_{3}$; 2) №№1 - 12 Ilmenite 1 (plagiogranite); 3) №№13 - 16 Ilmenite 1 (leucogranite); 4) №№ 17 - 24 Ilmenite 2 (leucogranite); 5) dash - element is not identified

Ilmenite 1

Crystallochemical formulae (correspond to the numbers in the table):

1. $\left(\mathrm{Fe}_{0.903} \mathrm{Mn}_{0.116}\right)_{1.019}\left(\mathrm{Ti}_{0.922} \mathrm{Al}_{0.092}\right)_{1.014} \mathrm{O}_{3} \quad$ 14. $\left(\mathrm{Fe}_{0.939} \mathrm{Mn}_{0.063}\right)_{1.002}\left(\mathrm{Ti}_{0.998} \mathrm{Al}_{0.067}\right)_{1.065} \mathrm{O}_{3}$

2. $\left(\mathrm{Fe}_{1.017} \mathrm{Mn}_{0.068}\right)_{1.085}\left(\mathrm{Ti}_{0.858} \mathrm{Al}_{0.123} \mathrm{~V}_{0.006}\right)_{0.987} \mathrm{O}_{3} \quad$ 15. $\left(\mathrm{Fe}_{0.699} \mathrm{Mn}_{0.04}\right)_{0.739}\left(\mathrm{Ti}_{1.073} \mathrm{Al}_{0.077}\right)_{1.15} \mathrm{O}_{3}$

3. $\left(\mathrm{Fe}_{0.976} \mathrm{Mn}_{0.053}\right)_{1.029}\left(\mathrm{Ti}_{0.885} \mathrm{Al}_{0.133}\right)_{1.018} \mathrm{O}_{3} \quad$ 16. $\left(\mathrm{Fe}_{0.689} \mathrm{Mn}_{0.028}\right)_{0.717}\left(\mathrm{Ti}_{1.052} \mathrm{Al}_{0.119}\right)_{1.171} \mathrm{O}_{3}$

4. $\left(\mathrm{Fe}_{1.043} \mathrm{Mn}_{0.073}\right)_{1.116}\left(\mathrm{Ti}_{0.937} \mathrm{~V}_{0.004}\right)_{0.941} \mathrm{O}_{3}$

5. $\left(\mathrm{Fe}_{0.947} \mathrm{Mn}_{0.133}\right)_{1.08}\left(\mathrm{Ti}_{0.825} \mathrm{Al}_{0.181}\right)_{1.006} \mathrm{O}_{3}$

Ilmenite 2

6. $\left(\mathrm{Fe}_{1.021} \mathrm{Mn}_{0.066}\right)_{1.087} \mathrm{Ti}_{0.956} \mathrm{O}_{3}$

17. $\left(\mathrm{Fe}_{0.804} \mathrm{Mn}_{0.252}\right)_{1.056} \mathrm{Ti}_{0.971} \mathrm{O}_{3}$ 
7. $\left(\mathrm{Fe}_{0.973} \mathrm{Mn}_{0.102}\right)_{1.075} \mathrm{Ti}_{0.962} \mathrm{O}_{3}$

8. $\left(\mathrm{Fe}_{0.883} \mathrm{Mn}_{0.193}\right)_{1.076} \mathrm{Ti}_{0.961} \mathrm{O}_{3}$

9. $\left(\mathrm{Fe}_{0.881} \mathrm{Mn}_{0.096}\right)_{0.977} \mathrm{Ti}_{1.011} \mathrm{O}_{3}$

10. $\left(\mathrm{Fe}_{0.832} \mathrm{Mn}_{0.094}\right)_{0.926}\left(\mathrm{Ti}_{1.01} \mathrm{~V}_{0.01}\right)_{1.02} \mathrm{O}_{3}$

11. $\left(\mathrm{Fe}_{0.884} \mathrm{Mn}_{0.113}\right)_{0.997}\left(\mathrm{Ti}_{0.995} \mathrm{~V}_{0.007}\right)_{1.002} \mathrm{O}_{3}$

12. $\left(\mathrm{Fe}_{0.812} \mathrm{Mn}_{0.164}\right)_{0.976}\left(\mathrm{Ti}_{0.997} \mathrm{~V}_{0.012}\right)_{1.009} \mathrm{O}_{3}$

13. $\left(\mathrm{Fe}_{1.023} \mathrm{Mn}_{0.059}\right)_{1.082} \mathrm{Ti}_{0.958} \mathrm{O}_{3}$

In comparison with $\mathrm{V}, \mathrm{Nb}$ accumulation is favoured by the alkalinity of the melt, and the concentration increase is fully matched to these rocks alkalinity increase, particularly of potassium trend.

Thus, ilmenite presence in two generations in granatoids indicates its crystallization to magmatic stage within the wide range of temperature. According to the data [4] ilmenite can also be formed in the moderate and intensive oxidizing conditions, where a certain amount of $\mathrm{Fe}^{3+}$ is present in the ilmenite composition. If there is $\mathrm{Fe}^{3+}$ in Ilmenite 2 composition, both the increased amount of manganese and the increased alkalinity of leucogranites as the final stage derivatives are identified.

\section{Conclusion}

The research analysis of the accessory ilmenite for Devonian granatoids in polyphase Aleisk-Zmeinogorsk complex allows to conclude the following:

1. Ilmenite in granitoids of various phases is distributed irregularly and forms low concentrations; plagiogranits of the major phase are significally enriched by ilmenite.

2. The accessory ilmenite is present in granitoids in two generations singled out at different magmatic stages of alumosilicate melt crystallization.

3. Typomorphic features for ilmenite generations identification have been established: Ilmenite1, mostly crystalline-faced form, presence of $\mathrm{V}$ admixture, low aluminia content; Ilmenite 2, with xenomorphic or platy grains, $\mathrm{Nb}$ presence, low aluminia content, the increased amount of manganese.

4. The $\mathrm{V}$ admixture presence in Ilmenite1, $\mathrm{Nb}$ admixture presence in Ilmenite 2. This is the early-phase plagiogranites typomorphic feature - the geochemical trend for $\mathrm{V}$, leucogranites final phase - for $\mathrm{Nb}$.

\section{References}

1 Lyakhovitch V. V. Accessory rock minerals. Course book. Moscow. Nedra. 296, (1979)

2 Turkin Y. A., Novoselov K. L. Petrologo-gechemical features of Devonian granitoids in Rudny Altai N-W, 2012, Izvestiya TPU, Volume 321, Issue 1, pp 5-15

3 Novoselov K. L., Turkin Y. A. Typomorphism of accessory titanomagnetite for Devonian granitoids in Rudny Altai $N$-W, 2014, Izvestiya TPU, Volume 324, Issue 1, pp 5-16

4 Nikolskiy N. S. Fluid regime of endogenous mineral formation. Moscow. Nauka. 199, (1987)

$5 \quad$ Vakhrushev V. A. Ore minerals of igneous metamorphic rocks. Handbook. Moscow. Nedra. 199, (1988)

6 Kryvdik S. G. Geochemical features of ilmenites from the alkaline complexes of the Ukrainian shield: LA-ICP MS data, 2014, Geochemistry International, Volume 52, Issue 4, pp 287-295

$7 \quad$ Alekseev V. I., Marin Yu. B. Accessory mineralization of rocks from late cretaceous intrusive series with Li $-F$ granites in the Far East, 2015, Geology of Ore Deposits, Volume 57, Issue 7, pp 537-551

8 Makarov E. C. Isomorphism of atoms in crystals. Moscow. Atomizdat, 288, (1973)

9 Minerals. Reference Book Volume 2, Issue 3. Moscow. Nauka, 675, (1967)

10 Borisenko L. F. Vanadium (mineralogy, geochemistry and types of endogenous deposits). Moscow. Nedra. 192 (1973) 